\title{
Invasive ants reduce abundance of small rainforest skinks
}

\author{
Lori Lach $^{1}$ (D) Dylan Case ${ }^{1} \cdot$ Peter Yeeles $^{1}$ (D) $\cdot$ Conrad J. Hoskin ${ }^{2}$ (D)
}

Received: 27 August 2021 / Revised: 16 December 2021 / Accepted: 2 January 2022 /

Published online: 10 January 2022

(C) The Author(s) 2022

\begin{abstract}
Invasive ants are among the world's most damaging invasive species, often directly or indirectly affecting native fauna. Insecticidal baits are the main method for suppressing or eradicating invasive ant populations, but their use must be considered against potential for unintended effects on native organisms. The invasive yellow crazy ant (Anoplolepis gracillipes) is widespread in the tropics, particularly on islands, where they have displaced a range of invertebrates. Effects of this ant on vertebrates, and in continental ecosystems generally, are less studied. We investigated the effects of yellow crazy ants and bait application on rainforest skinks and their invertebrate prey. We compared skink and skink prey abundance across four replicated rainforest site categories: high and low yellow crazy ant sites had both been baited but differed in yellow crazy ant activity; control sites had never had yellow crazy ants or been baited; and buffer sites had never had yellow crazy ants but had been baited. We recorded significantly lower abundance of two small skink species (Lygisaurus laevis and Saproscincus tetradactylus) in high yellow crazy ant sites compared to all other site categories. The differences persisted even after baiting reduced yellow crazy ant activity by $97.8 \% \pm 0.04 \%$ (mean \pm SD). A larger rainforest skink species (Carlia rubrigularis) was not negatively affected by yellow crazy ant invasion. Skink prey abundance was significantly lower in high yellow crazy ant sites compared to control sites and low yellow crazy ant sites, but not compared to buffer sites. These differences did not persist following baiting. We found no evidence that baiting negatively affects skinks or their invertebrate prey. Our data suggest that yellow crazy ants, but not the bait used to treat them, pose a direct threat to small rainforest skinks.
\end{abstract}

Keywords Biodiversity hotspot - Baiting - Indirect effects · Invertebrate prey $\cdot$ Wet Tropics World Heritage Area $\cdot$ Yellow crazy ants

Communicated by Akihiro Nakamura.

This article belongs to the Topical Collection: Invasive species.

Lori Lach

lori.lach@jcu.edu.au

1 College of Science and Engineering, James Cook University, PO Box 6811, Cairns, QLD 4870, Australia

2 College of Science and Engineering, James Cook University, 1 James Cook Drive, Townsville, QLD 4811, Australia 


\section{Introduction}

Invasive ants are a threat to conservation in many parts of the world because they can alter the composition and functioning of ecosystems. Most of the documented effects of invasive ants on native invertebrate species are considered direct and are attributed to the high abundance invasive ants achieve (Holway et al. 2002). Invasive ants outcompete or prey on native ants and other invertebrates, often leading to population declines or local extinctions (Clarke et al. 2021). Documented effects of invasive ants on vertebrate populations are less common (Lach and Hooper-Bùi 2010), but have been observed as direct effects via predation and harassment (Allen et al. 2004; Plentovich et al. 2018).

The importance of indirect effects of invasive species is becoming more widely recognized in invasion ecology (Northfield et al. 2018; White et al. 2006). Indirect effects are those that are mediated through one or more additional species. Indirect effects of invasive ants are more difficult to discern but may be no less significant in their consequences for native species and ecosystem function. For example, the coastal horned lizard (Phrynosoma coronatum) in southern California suffered significant declines when the invading Argentine ant (Linepithema humile) displaced much of the native ant fauna that juvenile lizards rely on for food (Suarez et al. 2000). Similarly, low invertebrate abundance associated with red imported fire ants (Solenopsis invicta) resulted in low survival of juvenile endangered Attwater's prairie chickens (Tympanuchus cupido attwateri) (Morrow et al. 2015).

Another mechanism by which native fauna may be affected indirectly by ant invasions is if they or their prey are susceptible to the treatments applied to reduce or eradicate ant populations. Invasive ant populations are often treated with insecticidal baits. Baits are typically not specific to the target ant species and may kill other ants and invertebrates (Hoffmann et al. 2016; McNaught et al. 2014; Plentovich et al. 2010; Sakamoto et al. 2019; Schlappi et al. 2021). Exposure to non-target taxa may be reduced with the use of containerized baits or other methods of decreasing attraction or access to baits (Buczkowski 2017; Choe et al. 2010), but these are not always effective or practical for large scale use. For broad-scale application of bait, a common presumption is that highly abundant target ants will dominate the baits and leave little for non-target organisms to consume (Hoffmann et al. 2016). However, bait dominance is increasingly unlikely as invasive ant abundance declines with successive bait applications, particularly if populations are treated until eradication. Therefore, more bait may be available for consumption by non-target organisms, such as native ants or other invertebrates (Sakamoto et al. 2019). Bait that diminishes or poisons populations of non-target invertebrates may also indirectly harm predators that feed on them (Peveling et al. 2003). Land managers recognize the risks of insecticidal baits to non-target fauna, and insufficient knowledge of how to manage or mitigate non-target impacts is a key reason for the low number of ant eradications attempted in conservation areas (Hoffmann et al. 2016).

The yellow crazy ant (Anoplolepis gracilipes) (Fig. 1a) is widespread in the tropics but documented reports of its environmental effects within its introduced range are largely limited to island ecosystems. Yellow crazy ants achieve high abundance via accessing honeydew from sap-sucking insects (Abbott and Green 2007; Lach et al. 2020) and have been associated with declines in invertebrate taxa, such as ants, spiders, and crabs, across multiple islands in its introduced range (Holway et al. 2002; Kaiser-Bunbury et al. 2014; Lach and Hooper-Bùi 2010). Effects on vertebrates are less studied. Population level declines have been recorded for wedgetail shearwater chicks (Adrena pacifica) harassed by yellow 


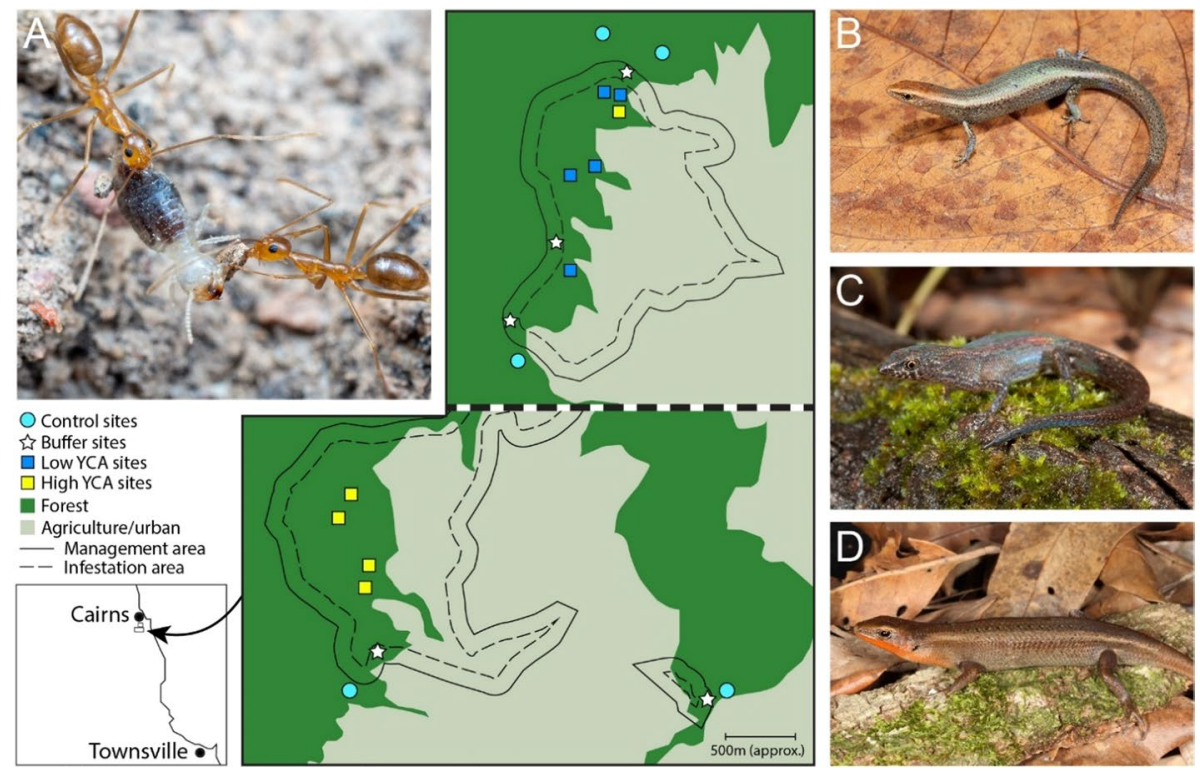

Fig. 1 Schematic map showing the location of the study sites in relation to the infestation area just south of Cairns, Queensland and photos of main species of interest. Forested land is shown in dark green while agriculture or urban land is shown in light green. High yellow crazy ant sites are shown as yellow squares, low yellow crazy ant sites as blue squares, buffer sites as white stars, and control sites as cyan circles. The dashed black line shows the extent of the yellow crazy ant infestation while the solid black line shows the extent of the management (i.e., treatment) area. Photos: A yellow crazy ant attacking a termite; B Lygisaurus laevis; C Saproscincus tetradactylus; D Carlia rubrigularis. Photo credits: Peter Yeeles (A); Anders Zimny (B, C); Conrad Hoskin (D)

crazy ants in Hawai'i and for the emerald dove (Chalcophaps indica natalis) and juvenile Christmas Island thrush (Turdus poliocephalus erythropleurus), due to direct and indirect effects of the ants on Christmas Island (Davis et al. 2008; O'Dowd et al. 2003). But population level effects of yellow crazy ants are unknown, or unreported for the critically endangered Christmas Island flying fox (Pteropus natalis) on Christmas Island and Daito whiteeye (Zosterops japonicus daitoensis) and bull-headed shrike fledglings (Lanius bucephalus) on Minami-daito island, Japan, which are also all harassed by the ants (Dorrestein et al. 2019; Matsui et al. 2009). Evidence for effects of yellow crazy ants on herpetofauna is much more tenuous. The ants had been implicated in the population declines of four native skink species on Christmas Island (Smith et al. 2012), but a recent retrospective expert elicitation concluded there was little spatial concordance between the lizard declines and the highest densities of yellow crazy ants (Emery et al. 2021). Feare (1999) asserted that on Bird Island, in the Seychelles, the introduction of yellow crazy ants resulted in the disappearance of an endemic skink but provided no evidence.

Effects of yellow crazy ants in continental ecosystems, which may be more robust to invasions generally due to higher community complexity (Simberloff 1995), have received little attention to-date. The single published study of yellow crazy ant effects on continental invertebrate communities found negative correlations between yellow crazy ant abundance and native ant abundance and richness, but no significant relationships between yellow crazy ants and other macroinvertebrates (Hoffmann and Saul 2010). There have been no 
studies on the effect of yellow crazy ants on continental vertebrate species or communities. Thus, questions remain about the broader impacts of these ants on vertebrates and in continental ecosystems. The effects of the ants relative to their treatment also requires investigation.

We investigated effects of yellow crazy ants, and the bait used to treat them, on rainforest skinks and their invertebrate prey in a large continental infestation of yellow crazy ants threatening the Wet Tropics World Heritage Area in northeastern Australia. The infestation is subject to a large management program, with the aim of eradication. We compared skink and skink prey abundance across replicate rainforest sites with different exposure to yellow crazy ants and bait to answer the questions (1) have yellow crazy ants affected the abundance of rainforest skinks?; and if so, (2) have the effects been mediated by declines in skink prey?; and (3) Is there a separate effect of the bait on either skinks or skink prey? (Fig. 2) We anticipated that if skinks were affected by any mechanism, they would be slow to recover or recolonize due to their lower long-distance dispersal capabilities and slower life cycles relative to insects. We expected that skink prey would be directly affected by yellow crazy ants where the ants were in higher abundance and by the bait where yellow crazy ant abundance was low or absent (because the invasive ants were not there in sufficient abundance to dominate it). We predicted that due to short life cycles and strong dispersal in most groups, skink prey would recover relatively quickly following baiting, either due to reduction of yellow crazy ants or recovery from effects of bait.

\section{Methods}

\section{Site selection and history}

Yellow crazy ants are thought to be native to south or southeast Asia (Janicki et al. 2016; Wetterer 2005) and were first recorded in the Cairns region in 2001 (Csurhes and Hankamer 2012). Despite some treatment efforts, by 2011 they had invaded rainforest in and around the Wet Tropics World Heritage Area (Lach and Barker 2013). By 2017, when the study was conducted, 260 hectares of rainforest in the region were under treatment for yellow crazy ants.

We selected 20 survey sites of similar canopy cover and habitat structure in complex notophyll vine rainforest or successional rainforest complexes southwest of Cairns, Queensland (Fig. 1 map). We selected the sites based on yellow crazy ant infestation and baiting history from data collected by the Wet Tropics Management Authority as part of the Yellow Crazy Ant Eradication Program in the area. Each site was a circular area of

Fig. 2 Conceptualization of the effects tested in this study. Dotted arrows, which are accompanied by question marks, indicate an effect tested in this study, and solid arrows indicate a known or presumed positive $(+)$ or negative (-) effect. Arrowheads indicate the direction of effect

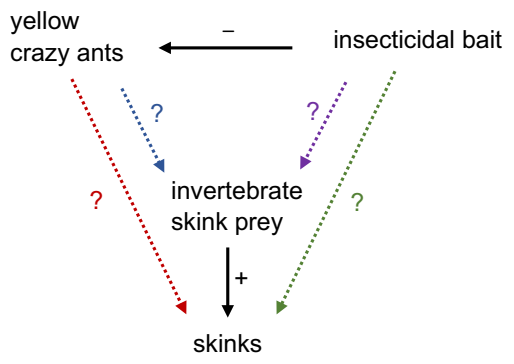


$50 \mathrm{~m}$ diameter $\left(1963 \mathrm{~m}^{2}\right)$. The 20 sites comprised five replicates of four different site categories based on baiting history and management definitions of yellow crazy ant activity: (1) 'control sites' had never been inhabited by yellow crazy ants or baited; (2) 'buffer sites' did not have yellow crazy ants, were within $100 \mathrm{~m}$ of a yellow crazy ant infestation and had been baited; (3) 'low' yellow crazy ant sites had sparse yellow crazy ant activity in the two years leading up to the study and had been baited; (4) 'high' yellow crazy ant sites had high yellow crazy ant activity in the two years leading up to the study and had been baited (Online Resource 1). The difference in yellow crazy ant activity between high and low yellow crazy ant sites likely reflects the differences in opportunity for population growth between establishment and first treatments; yellow crazy ants were likely discovered and treated, and thus prevented from growing, sooner after establishment in sites here considered as having low yellow crazy ant activity than at sites in which they became highly abundant. No known yellow crazy ant infestations are left unbaited in this region so it was not possible to survey in sites with yellow crazy ants that had not received bait.

All but the control sites had been baited by the eradication program once or twice per year with a pelletized S-methoprene-based product (Engage $P ®$ or Engage $+\circledR$ ) at $2 \mathrm{~kg} / \mathrm{ha}$ and once per year with a pelletized fipronil-based product (AntOff®) at $5 \mathrm{~kg} / \mathrm{ha}$ between 2014 and 2016 (Fig. 3). S-methoprene is an insect juvenile hormone analogue (also referred to as an insect growth regulator) and acts by disrupting larval molts and queen egg-laying (Yeeles et al. 2021). S-methoprene effects on reptiles are not well-studied, but risks are considered to be low (Rexrode et al. 2008). However, as is the case with many insecticides, risk profiles for reptiles are based on effects in birds and mammals, which may not be appropriate (Freitas et al. 2020; Hopkins 2000). Likewise, effects of fipronil on reptiles have not been well-studied. Nonetheless, fipronil is a neurotoxin and, based on a single study, is considered highly toxic to lizards $\left(\mathrm{LD}_{50}\right.$ for Acanthodactylus dumerili [Lacertidae] is $30 \mu \mathrm{g}$ fipronil per gram body weight)(Tingle et al. 2003). Yellow crazy ant activity declined by $90-100 \%$ in the weeks following fipronil-based bait application, whereas declines following application of the insect growth regulator products were more variable

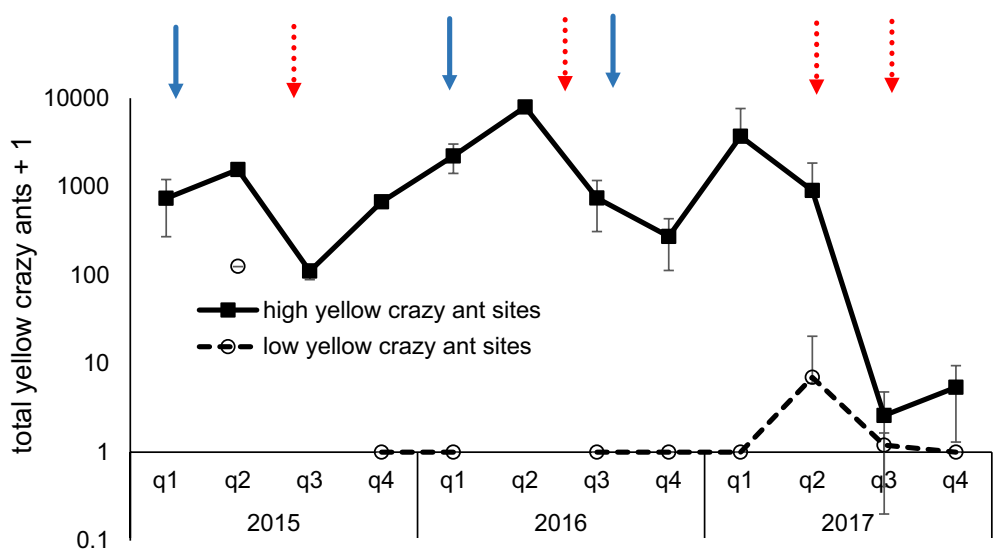

Fig. 3 The number of yellow crazy ants +1 (to enable log scaling) ( \pm SD) attracted to 10 lure stations after $60 \mathrm{~min}$ at fixed transects nearest to the study sites between 2015 and 2017. Note the log scale. Aerial baiting with an IGR-based corn grit product occurred in the first quarter of 2015 and first and third quarters of 2016 (blue solid arrows) and with a pelletized fipronil-based product during the third quarters in 2015 and 2016 , and during the second quarter of 2017 (red dashed arrows) 
and occurred over several months (Online Resource 1, Yeeles et al. unpublished data). Yellow crazy ant activity recovered rapidly at high yellow crazy ant sites between December and May 2015 and 2017 when our surveys commenced (Fig. 3).

\section{Surveys}

We obtained measures of skink and skink prey richness and abundance at the 20 sites on warm sunny days, with four repeat visits to each site: in mid-April to early May (round 1), late May to mid-June (round 2), mid to late-July (round 3), and mid-late August (round 4), yielding 80 total surveys. A single observer (DC), blind to all site categories throughout the study, conducted all skink surveys, collected and sorted the invertebrate samples, and assessed habitat as described below. Site visits commenced $90 \mathrm{~min}$ to $2 \mathrm{~h}$ after sunrise (between 7:45 and 9:30 a.m.), when it became warm enough for skinks and insects to be active and continued until three or four sites were completed around midday. Typically, the sites visited in a morning represented at least two different categories. In between rounds 1 and 2, and rounds 3 and 4, the Yellow Crazy Ant Eradication Program aerially baited all but the control sites with the fipronil-based pelletized bait at a rate of $5 \mathrm{~kg} / \mathrm{ha}$.

\section{Skinks}

For each survey at each site, the observer recorded the time and temperature, and then walked for $30 \mathrm{~min}$ over a $500 \mathrm{~m}$ distance around and within the $50 \mathrm{~m}$ diameter circle following a standard pattern of movement. The observer first walked the perimeter of the site and then zigzagged through the site, recording skink species, time of observation, and age class (juvenile, sub-adult, adult) of each individual skink encountered. The zigzag pattern allowed the observer to avoid barriers such as large boulders and impenetrable patches of wait-a-while vines (Calamus muelleri) and focus on likely microhabitats, such as sunspots, where skinks were most likely to be encountered. Skinks were not captured or handled during these surveys. Pilot surveys prior to systematic surveys revealed that three leaf-litter litter-dwelling species co-exist at the sites: Lygisaurus laevis (Fig. 1b), Saproscincus tetradactylus (Fig. 1c), and Carlia rubrigularis (Fig. 1d). These pilot surveys enabled training in identification from a distance, and the three species were then readily identified by sight in the systematic surveys. Carlia rubrigularis grow to approximately $60 \mathrm{~mm}$ snout-to-vent length (Singhal et al. 2018; Wilson 2015) and greater than $3 \mathrm{~g}$ as adults (Wilhoft 1963), which is substantially larger than $L$. laevis and S. tetradactylus, which both grow to about $35 \mathrm{~mm}$ snout-to-vent and $0.75 \mathrm{~g}$ as adults (Goodman et al. 2007; Greer and Kluge 1980; Wilson 2015). All three skink species are entirely terrestrial, foraging and seeking refuge among leaf-litter, logs, and rocks. Saproscincus tetradactylus and L. laevis are largely restricted to areas with canopy cover, whereas $C$. rubrigularis also utilizes hotter environments on the rainforest edge (Kanowski et al. 2006; Wilson 2015; author observations).

In August 2017, habitat suitability was assessed for skinks at all sites. Ten randomly selected $1 \mathrm{~m}^{2}$ quadrats at each site were photographed between 11:00 a.m. and 1:00 p.m. on cloudless days. We used ImageJ to calculate the amount of sunlight hitting the ground in each quadrat, which was averaged over the ten photos at each site to calculate the average sunlight penetration. Additionally, a single observer who was blind to site category (DC) scored rock cover, log cover, and leaf litter cover for each quadrat on a scale from 1 to 5 for each variable, with 1 being lowest and 5 being highest. We used the medians of these as the values for each site. The primary aim of the habitat assessment 
was to provide relative measures of these aspects of skink habitat to include in the models and thereby control for any effect of these variables when testing for effects of yellow crazy ants and bait.

\section{Skink prey}

We sampled leaf litter invertebrates because of their importance as prey for skinks and because invertebrates are often adversely affected by invasive ants and may be affected by bait. During each site visit, the observer (blind to site category) used randomly selected bearings and distances from the centre of the site to determine the location in which to place a $1 \mathrm{~m} \times 1 \mathrm{~m}$ quadrat. Invertebrates were sampled by first collecting all leaf litter within the quadrat for later hanging in a Berlese funnel to dry in the laboratory. Following removal of the leaf litter, a second person, also blind to site category, collected macroinvertebrates from the quadrat for $15 \mathrm{~min}$. Two quadrats were sampled per site visit for each of the five sites per treatment per round, yielding a total of 10 invertebrate samples from each treatment per round, and 160 samples in total.

In the laboratory, we sorted specimens obtained from the Berlese funnels and active collections on each quadrat to order and pooled these from both collection methods. We a priori classified the following invertebrate families as prey for skinks in this habitat (based on data in Manicom and Schwarzkopf 2011; Wilhoft 1963): Araneae, Blattidae, Coleoptera, Diptera, Hemiptera, Hymenoptera, Isopoda, Lepidoptera, and Orthoptera. As such, we report here only the analyses for these taxa.

\section{Statistical analyses}

We tested for the effects of site category and survey round on skinks and skink prey with generalized linear mixed models. Because skink body size and microhabitat preferences may affect susceptibility to yellow crazy ants, we ran two separate models to test for effects on skinks: one with the pooled abundance of the smaller skinks, L. laevis and S. tetradactylus as the response variable, and the other with the larger skink, C. rubrigularis, as the response variable. The abundance of small skinks was too low to run separate models for each species and retain all the parameters of interest. Due to the rarity of juvenile and sub-adult skinks observed, we also combined all age classes within the two models.

We included an interaction term between site category and survey round, but dropped this parameter when its inclusion did not improve model fit by two or more $\Delta$ AICc (Burnham and Anderson 2002). We included site as a random effect to account for repeated site visits. We used Poisson error distributions for all models, and re-fit over-dispersed models using observation level random effects (Harrison 2014). Rock abundance, log abundance, leaf litter cover, light penetration, and temperature were assessed for collinearity using Variance Inflation Factor (Zuur et al. 2010). All Variance Inflation Factors were $<3$, so we included all of these habitat variables as fixed covariates in our three models. We tested differences among site categories in each survey round post-hoc using Tukey HSD. We conducted all analyses in R (version 3.6.1; R Core Team 2019) using packages 'Ime4' (Bates et al. 2015), 'vegan' (Oksanen et al. 2019), and 'emmeans' (Lenth 2019). 


\section{Results}

The baiting that occurred in between our first and second rounds of surveys reduced yellow crazy ant abundance on lures at the closest monitoring sites by $97.8 \% \pm 0.04 \%$ (mean \pm SD) at our high yellow crazy ant density sites (Fig. 3). Subsequent monitoring before our survey rounds 3 and 4 revealed that yellow crazy ant activity had declined to below detectable levels at our high yellow crazy ant sites. At our low yellow crazy ant sites, yellow crazy ants had declined to below detectable levels prior to our skink surveys, due to previous baiting (Fig. 3, Online Resource 1).

\section{Skinks}

We recorded 641 individual skinks across the 80 surveys. Of these, 381 records were of $C$. rubrigularis and 260 were of the smaller skinks L. laevis (199 sightings) and S. tetradactylus (61 sightings). Of the 381 C. rubrigularis sightings, 234 (61.4\%) were adults, 105 (27.6\%) were sub-adults, and 42 (11.0\%) were juveniles. For L. laevis, 145 sightings were adults, 35 (17.6\%) were sub-adults, and 19 (9.5\%) were juveniles, and for $S$. tetradactylus 43 were adults $(70.5 \%), 10(16.4 \%)$ were sub-adults, and 8 (13.1\%) were juveniles. None of the juvenile small skinks were observed in high yellow crazy ant sites, and about half of them (9/19 for L. laevis, and 4/8 for S. tetradactylus) were observed in control sites.

We observed only 7 total L. laevis (6 adult, and 1 sub-adult), and no S. tetradactylus at the high yellow crazy ant sites (Online Resource 2), which resulted in a significantly lower mean abundance of small skinks at high yellow crazy ant sites compared to all other site categories (Tables 1 and 2; Fig. 4a). Small skink abundance did not vary among the other three site categories in any round (Table 2; Fig. 4a), indicating that low yellow crazy ant activity and baiting did not have measurable effects on small skink abundance. Temperature, rock abundance, and light penetration were all positively associated with small skink abundance, whereas log abundance, prey abundance, and leaf litter were not significant predictors of small skink abundance (Tables 1 and 2).

In contrast to small skink abundance, the effect of yellow crazy ants and baiting on abundance of $C$. rubrigularis varied in direction of effect and by round (Fig. 4b, Table 1). In rounds 2 and 3, C. rubrigularis abundance was significantly higher at sites with low yellow crazy ant activity than at buffer sites or sites with high yellow crazy ant activity but did not differ from control sites (Fig. 2b). Carlia rubrigularis abundance did not differ among site categories in rounds 1 and 4 . Carlia rubrigularis abundance was positively associated with temperature but not with any of the other environment or habitat variables (Tables 1 and 2).

\section{Skink prey}

We captured and identified to order 3495 invertebrates, of which 2277 were invertebrates that we classified as potential skink prey: 326 Araneae, 82 Blattidae, 222 Coleoptera, 343 Diptera, 130 Hemiptera, 391 Hymenoptera, 395 Isopoda, 267 Lepidoptera, and 121 Orthoptera. The effect of site category on skink prey abundance varied by round, as evidenced by the significant site category $\times$ round interaction (Tables 1 and 2; Fig. 3c). Skink prey abundance was significantly lower in the high yellow crazy ant sites compared to control and low yellow crazy ant sites in round 1 (Fig. 4c), which occurred before the first baiting of the year. Post-hoc comparisons yielded no other significant differences among 
Table 1 Results of generalized linear mixed effects models for small skink abundance, C. rubrigularis abundance, and skink prey abundance. Significant effects are in bold

\begin{tabular}{|c|c|c|c|}
\hline Response and explanatory variables & df & $\chi^{2}$ & $p$ \\
\hline \multicolumn{4}{|l|}{ Small skink abundance } \\
\hline Intercept & 1 & 16.75 & $<0.001$ \\
\hline Site category & 3 & 32.51 & $<0.001$ \\
\hline Survey round & 3 & 10.10 & 0.018 \\
\hline Temperature & 1 & 4.99 & 0.023 \\
\hline Light & 1 & 4.18 & 0.041 \\
\hline Rock cover & 1 & 15.28 & $<0.001$ \\
\hline Log cover & 1 & 0.66 & 0.416 \\
\hline Leaf litter cover & 1 & 0.06 & 0.807 \\
\hline Skink prey abundance & 1 & 0.68 & 0.411 \\
\hline \multicolumn{4}{|l|}{ C. rubriglaris abundance } \\
\hline Intercept & 1 & 0.56 & 0.454 \\
\hline Site category & 3 & 10.41 & 0.015 \\
\hline Survey round & 3 & 12.06 & 0.007 \\
\hline Site category $\times$ survey round & 9 & 27.16 & 0.001 \\
\hline Temperature & 1 & 17.97 & $<0.001$ \\
\hline Light & 1 & 2.32 & 0.127 \\
\hline Rock cover & 1 & 1.56 & 0.211 \\
\hline Log cover & 1 & 0.87 & 0.349 \\
\hline Leaf litter cover & 1 & 2.23 & 0.135 \\
\hline Skink prey abundance & 1 & 1.13 & 0.268 \\
\hline \multicolumn{4}{|l|}{ Skink prey abundance } \\
\hline Intercept & 1 & 259.0 & $<0.001$ \\
\hline Site category & 3 & 15.6 & 0.001 \\
\hline Survey round & 3 & 13.63 & 0.003 \\
\hline Site category $\times$ survey round & 9 & 27.00 & 0.001 \\
\hline Temperature & 1 & 0.35 & 0.56 \\
\hline Light & 1 & 0.03 & 0.87 \\
\hline Rock cover & 1 & 0.18 & 0.67 \\
\hline Log cover & 1 & 0.20 & 0.66 \\
\hline Leaf litter cover & 1 & 1.27 & 0.26 \\
\hline
\end{tabular}

site categories within rounds (Fig. 3c), but this was not due to a significant increase in skink prey at high yellow crazy ant sites between rounds 1 and $2(\beta=-0.79 \pm 0.35$ (SE), $\mathrm{z}=-2.27, \mathrm{p}=0.10$ ) following the decline in yellow crazy ant abundance at these sites (Fig. 2). None of the environmental variables were significant predictors of skink prey abundance (Tables 1 and 2).

\section{Discussion}

We tested whether abundance of rainforest skinks and their invertebrate prey were affected by yellow crazy ant abundance and baiting for these ants. The most striking finding of this study is that abundance of two species of small rainforest skinks, L. laevis and S. tetradactylus, was significantly lower in high yellow crazy ant sites compared to low or no yellow 
Table 2 Parameter estimates ( $\beta$ and SE) from generalised linear mixed models testing responses of small skink abundance, $C$. rubrigularis abundance, and skink prey abundance

\begin{tabular}{|c|c|c|c|}
\hline Fixed treatment effects & $\begin{array}{l}\text { Small skink abundance } \\
\beta[\mathrm{SE}]\end{array}$ & $\begin{array}{l}\text { C. rubrigularis abundance } \\
\beta[\mathrm{SE}]\end{array}$ & $\begin{array}{l}\text { Skink prey abundance } \\
\beta[\mathrm{SE}]\end{array}$ \\
\hline Intercept & $1.63[0.40]^{\dagger}$ & $-0.45[0.60]$ & $3.38[0.21]^{\dagger}$ \\
\hline Site category (buffer) & $-0.98[0.49]^{*}$ & $1.29[0.71]$ & $-0.65[0.30] *$ \\
\hline $\begin{array}{l}\text { Site category (low yellow } \\
\text { crazy ant) }\end{array}$ & $-0.40[0.48]$ & $1.68[0.70]^{*}$ & $-0.35[0.30]$ \\
\hline $\begin{array}{l}\text { Site category (high yellow } \\
\text { crazy ant) }\end{array}$ & $-3.42[0.63] \dagger$ & $0.21[0.79]$ & $-1.34[0.35] \dagger$ \\
\hline Skink prey abundance & $-0.23[0.28]$ & $0.22[0.20]$ & NA \\
\hline Round 2 & $0.69[0.33]^{*}$ & $1.57[0.56] \dagger$ & $-0.23[0.28]$ \\
\hline Round 3 & $0.77[0.28] \dagger$ & $1.81[0.54] \dagger$ & $-0.47[0.27]$ \\
\hline Round 4 & $0.94[0.32] \dagger$ & $1.97[0.58] \dagger$ & $-1.03[0.29] \dagger$ \\
\hline Buffer round 2 & NA & $-1.61[0.66]^{*}$ & $0.56[0.39]$ \\
\hline $\begin{array}{l}\text { Low yellow crazy ant } \times \text { round } \\
2\end{array}$ & NA & $-0.71[0.64]$ & $0.43[0.39]$ \\
\hline $\begin{array}{l}\text { High yellow crazy ant } \times \text { round } \\
2\end{array}$ & NA & $-0.97[0.75]$ & $1.05[0.42]^{*}$ \\
\hline Buffer $\times$ round 3 & NA & $-2.00[0.67] \dagger$ & $0.88[0.40]^{*}$ \\
\hline $\begin{array}{l}\text { Low yellow crazy ant } \times \text { round } \\
3\end{array}$ & NA & $-0.43[0.60]$ & $0.32[0.40]$ \\
\hline $\begin{array}{l}\text { High yellow crazy ant } \times \text { round } \\
3\end{array}$ & NA & $-0.83[0.72]$ & $1.60[0.42]^{\dagger}$ \\
\hline Buffer $\times$ round 4 & NA & $-1.50[0.63]^{*}$ & $0.31[0.43]$ \\
\hline $\begin{array}{l}\text { Low yellow crazy ant } \times \text { round } \\
4\end{array}$ & NA & $-0.77[0.61]$ & $0.12[0.42]$ \\
\hline $\begin{array}{l}\text { High yellow crazy ant } \times \text { round } \\
4\end{array}$ & NA & $-0.11[0.67]$ & $1.73[0.44]^{\dagger}$ \\
\hline Temperature & $0.67[0.30]^{*}$ & $0.83[0.20]^{\dagger}$ & $0.08[0.14]$ \\
\hline Light & $0.79[0.38]^{*}$ & $0.53[0.35]$ & $-0.02[0.14]$ \\
\hline Rock cover & $1.40[0.36]^{\dagger}$ & $0.39[0.31]$ & $0.06[0.13]$ \\
\hline Log cover & $-0.30[0.37]$ & $-0.31[0.33]$ & $-0.06[0.13]$ \\
\hline Leaf litter cover & $-0.08[0.34]$ & $0.45[0.30]$ & $0.15[0.13]$ \\
\hline Null model (intercept only) & $0.94[0.35]^{\dagger}$ & $1.20[0.19]^{\dagger}$ & $2.80[0.08]^{\dagger} *$ \\
\hline $\mathrm{R}_{\mathrm{GLMM}(\mathrm{M})}^{2}$ & $72.2 \%$ & $58.5 \%$ & $47.1 \%$ \\
\hline $\mathrm{R}_{\text {GLMM(C) }}^{2}$ & $96.5 \%$ & $84.1 \%$ & $87.1 \%$ \\
\hline Null model-AICc & 437.5 & 408.6 & 609.5 \\
\hline Final model-AICc & 426.1 & 395.9 & 605.8 \\
\hline
\end{tabular}

The intercept is the estimate of round 1 control sites

$* \mathrm{p}<0.05,{ }^{\dagger}<0.01$

crazy ant sites across all sampling periods. In contrast, we found no evidence to suggest negative impacts of yellow crazy ants on the relatively larger skink, $C$. rubrigularis. Skink prey abundance was lower in high yellow crazy ant sites compared to all other site categories in the first round of surveys only. We found no evidence that baiting negatively affects skinks or their prey. Our study is one of the few studies that investigates both the effects of 

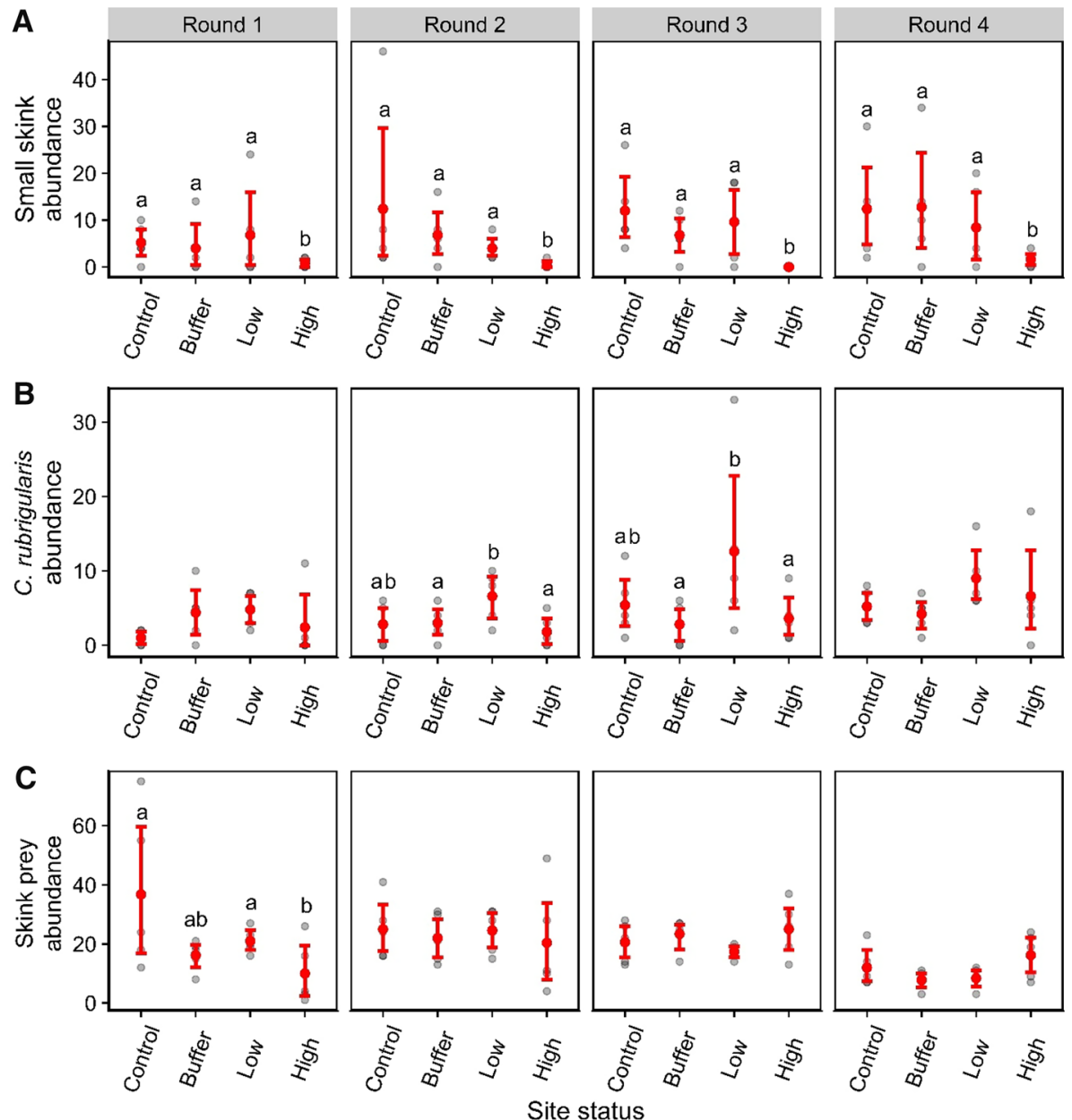

Fig. 4 Abundances of a small skinks, b C. rubrigularis, and c skink prey, by sampling round and site status. Site data points are shown in grey, with red points showing group means with a $95 \%$ CI. Groups with different letters within round differ significantly in post-hoc tests (at $\mathrm{p}<0.05$ using Tukey HSD). Aerial broadcast baiting with a fipronil-based product occurred between rounds 1 and 2 and between rounds 3 and 4

an invasive species and its management on native species and is the first we are aware of to report effects of this widespread invasive ant on continental vertebrates.

The near absence of small skinks in high yellow crazy ant sites and limited differences in skink prey among site categories suggest that yellow crazy ants have directly affected the smaller skinks, rather than indirectly affected them via reducing prey. When yellow crazy ants are abundant, they are capable of harassing and, sometimes killing, invertebrate and vertebrate organisms much larger than they are (Davis et al. 2010; Dorrestein et al. 2019; Lach et al. 2016; O’Dowd et al. 2003; Plentovich et al. 2018). With their formic acid spray, the ants can blind or maim organisms such as red land crabs (O'Dowd et al. 2003) and wedgetail shearwater chicks (Plentovich et al. 2018), and then prey on them or leave them susceptible to starvation. Both L. laevis and S. tetradactylus are entirely terrestrial, 
foraging and seeking refuge among leaf-litter, logs, and rocks, and therefore would overlap with preferred microhabitats of yellow crazy ants. Further, S. tetradactylus has a preference for moist microhabitats, such as creek-lines (Greer and Kluge 1980; Wilson 2015), which are also favoured by yellow crazy ants (Fluker and Beardsley 1970, author observations). The small adult body size of the two small skinks in our study (Goodman et al. 2007) and extremely small hatchling and juvenile size (estimated at about $0.1 \mathrm{~g}$ based on hatchling data for a larger congener of one of the species, Saproscincus mustelinus; Downes and Shine 1999) may mean they would have low capacity to withstand attack by even a relatively small number of yellow crazy ants.

Though yellow crazy ants declined steeply after baiting in between survey rounds 1 and 2, we did not observe recovery of small skink populations. Skink populations in our high yellow crazy ant sites would have experienced relatively high yellow crazy ant activity for at least two years prior to our study (Fig. 2, Online Resource 1) before experiencing the steep decline in yellow crazy ants following baiting after the round 1 survey. Despite the substantial decline in yellow crazy ants between our survey rounds 1 and 2, small skink abundance in high yellow crazy ant sites remained lower than all other sites for survey rounds $2-4$. The lack of recovery of small skinks at high yellow crazy ant sites after yellow crazy ants had been effectively removed is consistent with their natural history. Both $L$. laevis and S. tetradactylus have a clutch size of two (Greer and Kluge 1980; Turner 2006) and appear to breed primarily in the wet season, during which each female probably only lays one or two clutches (based on data for similar species, such as tropical Carlia, James and Shine 1985; and author observations). Additionally, these small skinks are likely to be of low mobility, so would be slow to recolonise from adjacent areas. Our surveys were conducted over months, whereas recovery of populations of these skink species may take years after removal of high density ant infestations.

Our findings for small skinks are in contrast to those for $C$. rubrigularis for which we did not discern a negative effect of yellow crazy ants. Adult $C$. rubrigularis are about double the length and four times the mass of the smaller skinks in our study (Goodman et al. 2007; Greer and Kluge 1980; Wilson 2015), but given the ability of yellow crazy ants to harm crabs and birds (O'Dowd et al. 2003; Plentovich et al. 2018), we do not think that the larger size alone would make $C$. rubrigularis less vulnerable to yellow crazy ant harassment. Rather, differences in behaviour or microhabitat use may be important. Carlia rubrigularis inhabits leaf litter and has a broadly similar ecology to L. laevis and S. tetradactylus. However, its use of hotter microhabitats and rainforest edges by $C$. rubrigularis may provide some refuge from the highest densities of yellow crazy ants, which prefer shaded, moist, and relatively cooler rainforest microhabitats. Intriguingly, C. rubrigularis was more common at low density yellow crazy sites than at buffer and high yellow crazy ant sites in rounds 2 and 3. Carlia rubrigularis may directly benefit from low density yellow crazy ant presence if they ate the ants but didn't suffer the negative impacts of harassment. Gut content analyses have found ants to be rare (Manicom and Schwarzkopf 2011) or moderately common (Wilhoft 1963) food items of this species. Another possibility is that low yellow crazy ant density reduces populations of competitors or predators at these sites. If so, there would have to be counteracting mechanisms to explain the lack of elevated $C$. rubrigularis abundance in high yellow crazy ant sites. Some Christmas Island reptiles have reportedly contracted to parts of the island with the highest yellow crazy ant abundance (Smith et al. 2012), but a more recent review of the data posits that yellow crazy ants may pose indirect, secondary, or synergistic threats to lizard populations (Emery et al. 2021). Clearly there is much more work to be done to elucidate the potential indirect mechanisms through which yellow crazy ants may affect forest reptile abundance. 
We found limited support for the hypothesis that yellow crazy ants affect skink prey abundance, and therefore think it unlikely that the rarity of small skinks in high yellow crazy ant sites is primarily driven by indirect effects. If yellow crazy ants were affecting the small skinks indirectly via decreasing their prey, we would expect that skink prey abundance would be significantly lower in high yellow crazy ant sites than in all other sites for at least the first survey round, before baiting reduced yellow crazy ant activity. In the first round, skink prey abundance was indeed significantly lower at high yellow crazy ant sites compared to control and low crazy ant sites. However, it was not lower compared to buffer sites. Therefore, we do not consider it as strong evidence of an effect of yellow crazy ants on skink prey. Moreover, the lack of differences in skink prey among site categories in subsequent rounds was not driven by significant recovery of skink prey in the high yellow crazy ant sites, but rather by some decline in skink prey abundance at control sites as well as variation within site categories. Yellow crazy ants had no significant detectable effects on invertebrate ordinal richness or abundance in the only other investigation of the ants' effects on continental non-ant invertebrates (Hoffmann and Saul 2010). These analyses do not preclude the possibility that yellow crazy ants are adversely affecting some specific taxonomic groups, as has been reported widely on islands (Holway et al. 2002; KaiserBunbury et al. 2014; Lach and Hooper-Bùi 2010). We are further investigating the effect of yellow crazy ants on invertebrates, with a multi-year dataset and a focus on native ants, and this will better explore impacts of yellow crazy ants and associated baiting on invertebrate communities. The lack of any observed declines of $C$. rubrigularis in high yellow crazy ant sites also undermines the hypothesis that yellow crazy ants indirectly affect skinks via reductions in their prey. We cannot rule out, however, that our order-level analysis of prey abundance masks negative effects of yellow crazy ants on particular prey taxa that may be more important to one or more of these skink species.

Our findings suggest that baiting does not directly affect skink populations. We would expect an effect of bait to have manifested as significantly lower skink abundance in buffer sites relative to control sites, especially in survey rounds 2 and 4, which occurred within weeks of baiting. For both the small skink species and C. rubrigularis, there were no significant differences in abundance between control and buffer sites in any round. While we have occasionally observed skinks touching baits, we did not expect baiting to cause population level declines of skinks. Both bait products applied are in pelletized form. Baits lying stationary on the forest floor are unlikely to be consumed by leaf-litter dwelling skinks like those in our study because predation in these species appears to be heavily movement-initiated (author observations). These skinks are 'active foragers', moving through the leaf-litter searching for prey visually. However, they may also be tongue-flicking to locate chemical cues (Cooper and Whiting 2000), which could lead them to consume baits. Buckmaster et al. (2014) assessed 40 reptilian species as likely to consume sausage-type baits and 13 as likely to consume hard polymer capsule baits used to control feral cats. Therefore, it is not superfluous to consider that pelletized bait applied for ant control may also have risks to reptiles. Studies that investigate these risks are very rare, however, and need to be able to separate the effect of the ant invader from the effects of its treatment to be conclusive. An assessment of the effect of the yellow crazy ant control program on the Christmas Island gecko (Lepidodactylus listeri) was inconclusive due to low and highly variable gecko captures (Stork et al. 2014), and also did not have baited areas that were not infested with yellow crazy ants as a comparison.

Our study found significant yellow crazy ant-associated declines in the abundance of two small skinks species, no measurable effects of yellow crazy ants on a larger skink species, limited evidence of yellow crazy ant impacts on skink prey at the ordinal level, and no 
evidence of adverse baiting effects on any of these groups. Our results raise concern over the impact of yellow crazy ants on lizards and other small vertebrates where the ants have invaded and are not being managed, globally, and for the Wet Tropics, should eradication fail. For example, the Wet Tropics has a diverse radiation of terrestrial-breeding microhylid frogs of very small size ( $<1 \mathrm{~g}$ adult body mass) and many other larger species of frogs that begin terrestrial life as very small metamorphs. Further research is needed to determine specific mechanisms of ant impact on small vertebrates and assess the degree to which body size (both among species and across life stages within species) and micro-habitat selection may ameliorate impacts within communities.

Supplementary Information The online version contains supplementary material available at https://doi. org/10.1007/s 10531-022-02360-6.

Acknowledgements We acknowledge the Djabuganjdji and Yidinjdji people as the original custodians of the land on which this research was conducted and recognize their continuing connection to land, waters, and culture. We thank all landholders who provided access and allowed us to work at the survey sites. We thank the Wet Tropics Management Authority for sharing yellow crazy ant survey data and for facilitating access to sites. We thank Lenny Murphy, Keely Glass, Shavaun Glover, and Riley Case for volunteering on the project.

Author contributions LL and CH designed the study. DC collected the data. PY analyzed the data and created the figures. LL led the writing of the manuscript with contributions from all authors.

Funding Open Access funding enabled and organized by CAUL and its Member Institutions. The work was supported by James Cook University Honours student funding and a Wet Tropics Management Authority student grant made available with funding from the Australian and Queensland governments.

Data availability The datasets generated during and/or analysed during the current study are available in the Research Data Australia repository: Lach, Lori; Yeeles, Peter; Hoskin, Conrad; Case, Dylan (2021): Rainforest skink and invertebrate prey abundance in sites with different yellow crazy ant activity and baiting history. James Cook University. https://doi.org/10.25903/fa6b-qz32

Code availability Not applicable.

\section{Declarations}

Conflict of interest Authors LL, DC, and PY declare that they have received funding from the Wet Tropics Management Authority; LL declares that she was serving on the Yellow Crazy Ant Eradication Program Steering Committee at the time this research was conducted; author $\mathrm{CH}$ has no relevant financial or nonfinancial interests to disclose.

Ethical approval Ethics approval obtained from James Cook University Animal Ethics Committee, approval A2419.

Consent to participate Not applicable.

Consent for publication All authors consent to publication.

Open Access This article is licensed under a Creative Commons Attribution 4.0 International License, which permits use, sharing, adaptation, distribution and reproduction in any medium or format, as long as you give appropriate credit to the original author(s) and the source, provide a link to the Creative Commons licence, and indicate if changes were made. The images or other third party material in this article are included in the article's Creative Commons licence, unless indicated otherwise in a credit line to the material. If material is not included in the article's Creative Commons licence and your intended use is not permitted by statutory regulation or exceeds the permitted use, you will need to obtain permission directly from the copyright holder. To view a copy of this licence, visit http://creativecommons.org/licenses/by/4.0/. 


\section{References}

Abbott KL, Green PT (2007) Collapse of an ant-scale mutualism in a rainforest on Christmas Island. Oikos 116:1238-1246. https://doi.org/10.1111/j.2007.0030-1299.15629.x

Allen CR, Epperson DM, Garmestani AS (2004) Red imported fire ant impacts on wildlife: a decade of research. Am Midl Nat 152:88-103

Bates D, McHler M, Bolker B, Walker S (2015) Fitting linear mixed-effects models using lme4. J Stat Softw. https://doi.org/10.18637/jss.v067.i01

Buckmaster T, Dickman CR, Johnston MJ (2014) Assessing risks to non-target species during poison baiting programs for feral cats. Plos One 9:e107788

Buczkowski G (2017) Prey-baiting as a conservation tool: selective control of invasive ants with minimal non-target effects. Insect Conserv Divers 10:302-309. https://doi.org/10.1111/icad.12230

Burnham KP, Anderson DR (2002) Model selection and multimodel inference: a practical information-theoretic approach. Springer, New York

Choe DH, Vetter RS, Rust MK (2010) Development of virtual bait stations to control Argentine ants (Hymenoptera: Formicidae) in environmentally sensitive habitats. J Econ Entomol 103:1761-1769. https:// doi.org/10.1603/ec10154

Clarke DA, Palmer DJ, McGrannachan C, Burgess TI, Chown SL, Clarke RH, Kumschick S, Lach L, Liebhold AM, Roy HE, Saunders ME, Yeates DK, Zalucki MP, McGeoch MA (2021) Options for reducing uncertainty in impact classification for alien species. Ecosphere 12:e03461. https://doi.org/10.1002/ ecs2.3461

Cooper WE, Whiting MJ (2000) Ambush and active foraging modes both occur in the scincid genus Mabuya. Copeia. https://doi.org/10.1643/0045-8511(2000)2000[0112:Aaafmb]2.0.Co;2

Csurhes S, Hankamer C (2012) Pest animal risk assessment: yellow crazy ant (Anoplolepis gracilipes). Biosecurity Queensland DoE, Economic Development and Innovation (ed), State of Queensland

Davis NE, O'Dowd DJ, Green PT, Mac Nally R (2008) Effects of an alien ant invasion on abundance, behavior, and reproductive success of endemic Island Birds. Conserv Biol 22:1165-1176. https://doi. org/10.1111/j.1523-1739.2008.00984.x

Davis NE, O’Dowd DJ, Mac Nally R, Green PT (2010) Invasive ants disrupt frugivory by endemic island birds. Biol Lett 6:85-88. https://doi.org/10.1098/rsbl.2009.0655

Dorrestein A, Todd CM, Westcott DA, Martin JM, Welbergen JA (2019) Impacts of an invasive ant species on roosting behavior of an island endemic flying-fox. Biotropica 51:75-83. https://doi.org/10.1111/btp. 12620

Downes SJ, Shine R (1999) Do incubation-induced changes in a lizard's phenotype influence its vulnerability to predators? Oecologia 120:9-18. https://doi.org/10.1007/s004420050827

Emery J-P, Mitchell NJ, Cogger H, Agius J, Andrew P, Arnall S, Detto T, Driscoll DA, Flakus S, Green P, Harlow P, McFadden M, Pink C, Retallick K, Rose K, Sleeth M, Tiernan B, Valentine LE, Woinarski JZ (2021) The lost lizards of Christmas Island: a retrospective assessment of factors driving the collapse of a native reptile community. Conserv Sci Pract 3:e358. https://doi.org/10.1111/csp2.358

Feare C (1999) Ants take over from rats on Bird Island, Seychelles. Bird Conserv Int 9:95-96

Fluker SS, Beardsley J (1970) Sympatric associations of three ants: Iridomyrmex humilis, Pheidole megacephala and Anoplolepis longipes in Hawaii. Ann Entomol Soc Am 63:1290-1296

Freitas LM, Paranaíba J, Peréz APS, Machado MRF, Lima FC (2020) Toxicity of pesticides in lizards. Hum Exp Toxicol 39:596-604. https://doi.org/10.1177/0960327119899980

Goodman BA, Krockenberger AK, Schwarzkopf L (2007) Master of them all: performance specialization does not result in trade-offs in tropical lizards. Evol Ecol Res 9:527-546

Greer AE, Kluge AG (1980) A new species of Lampropholis (Lacertilia:Scincidae) from the rainforests of northeastern Queensland. Occ Pap Mus Zool Univ Michigan 691:12

Harrison XA (2014) Using observation-level random effects to model overdispersion in count data in ecology and evolution. PeerJ 2:e616. https://doi.org/10.7717/peerj.616

Hoffmann BD, Saul WC (2010) Yellow crazy ant (Anoplolepis gracilipes) invasions within undisturbed mainland Australian habitats: no support for biotic resistance hypothesis. Biol Invasions 12:3093-3108

Hoffmann BD, Luque GM, Bellard C, Holmes ND, Donlan CJ (2016) Improving invasive ant eradication as a conservation tool: a review. Biol Conserv 198:37-49. https://doi.org/10.1016/j.biocon.2016.03.036

Holway DA, Lach L, Suarez AV, Tsutsui ND, Case TJ (2002) The causes and consequences of ant invasions. Annu Rev Ecol Syst 33:181-233. https://doi.org/10.1146/annurev.ecolsys.33.010802.150444

Hopkins WA (2000) Reptile toxicology: challenges and opportunities on the last frontier in vertebrate ecotoxicology. Environ Toxicol Chem 19:2391-2393. https://doi.org/10.1002/etc.5620191001

James C, Shine R (1985) The seasonal timing of reproduction-a tropical-temperate comparison in Australian lizards. Oecologia 67:464-474. https://doi.org/10.1007/bf00790016 
Janicki J, Narula N, Ziegler M, Guénard B, Economo EP (2016) Visualizing and interacting with largevolume biodiversity data using client-server web-mapping applications: the design and implementation of antmaps.org. Eco Inform 32:185-193

Kaiser-Bunbury CN, Cuthbert H, Fox R, Birch D, Bunbury N (2014) Invasion of yellow crazy ant Anoplolepis gracilipes in a Seychelles UNESCO palm forest. NeoBiota 22:43-57

Kanowski JJ, Reis TM, Catterall CP, Piper SD (2006) Factors affecting the use of reforested sites by reptiles in cleared rainforest landscapes in tropical and subtropical Australia. Restor Ecol 14:67-76. https://doi. org/10.1111/j.1526-100X.2006.00106.X

Lach L, Barker G (2013) Assessing the effectiveness of tramp ant projects to reduce impacts on biodiversity. Report for the Australian Government Department of Sustainability, Environment, Water, Population, and Communities, Canberra. https://www.environment.gov.au/biodiversity/invasive/ publications/tramp-ant-projects.

Lach L, Hooper-Bùi LM (2010) Consequences of ant invasions. In: Lach L, Parr CL, Abbott KL (eds) Ant ecology. Oxford University Press, Oxford, pp 261-286

Lach L, Volp TM, Greenwood TA, Rose A (2016) High invasive ant activity drives predation of a native butterfly larva. Biotropica. https://doi.org/10.1111/btp.12284

Lach L, Hoffmann BD, Moir ML (2020) Native and non-native sources of carbohydrate correlate with abundance of an invasive ant. Neobiota 63:155

Lenth R (2019) emmeans: estimated marginal means, aka least-squares means. R package version 1.4.3.01. https://CRAN.R-project.org/package=emmeans.

Manicom C, Schwarzkopf L (2011) Diet and prey selection of sympatric tropical skinks. Austral Ecol 36:485-496. https://doi.org/10.1111/j.1442-9993.2010.02181.x

Matsui S, Kikuchi T, Akatani K, Horie S, Takag M (2009) Harmful effects of invasive yellow crazy ant Anoplolepis gracilipes on three land bird species of Minami-daito Island. Ornithol Sci. https://doi. org/10.2326/048.008.0111

McNaught MK, Wylie FR, Harris EJ, Alston CL, Burwell CJ, Jennings C (2014) Effect of broadcast baiting on abundance patterns of red imported fire ants (Hymenoptera: Formicidae) and key local ant genera at long-term monitoring sites in Brisbane, Australia. J Econ Entomol 107:1307-1315. https://doi.org/10.1603/ec14008

Morrow ME, Chester RE, Lehnen SE, Drees BM, Toepfer JE (2015) Indirect effects of red imported fire ants on Attwater's prairie-chicken brood survival. J Wildl Manag 79:898-906. https://doi.org/10. 1002/jwmg.915

Northfield TD, Laurance SGW, Mayfield MM, Paini DR, Snyder WE, Stouffer DB, Wright JT, Lach L (2018) Native turncoats and indirect facilitation of species invasions. Proc R Soc B 285:20171936. https://doi.org/10.1098/rspb.2017.1936

O'Dowd DJ, Green PT, Lake PS (2003) Invasional "meltdown" on an oceanic island. Ecol Lett 6:812817. https://doi.org/10.1046/j.1461-0248.2003.00512.x

Oksanen J, Blanchet FG, Friendly M, Kindt R, Legendre P, McGlinn D, Minchin PR, O'Hara RB, Simpson GL, Solymos P, Stevens MHH, Szoecs E, Wagner H (2019) vegan: Community ecology package. R package version 2.5-6. https://CRAN.R-project.org/package=vegan

Peveling R, McWilliam AN, Nagel P, Rasolomanana H, Raholijaona RL, Ravoninjatovo A, Dewhurst CF, Gibson G, Rafanomezana S, Tingle CCD (2003) Impact of locust control on harvester termites and endemic vertebrate predators in Madagascar. J Appl Ecol 40:729-741. https://doi.org/10. 1046/j.1365-2664.2003.00833.x

Plentovich S, Swenson C, Reimer N, Richardson M, Garon N (2010) The effects of hydramethylnon on the tropical fire ant, Solenopsis geminata (Hymenoptera: Formicidae), and non-target arthropods on Spit Island, Midway Atoll, Hawaii. J Insect Conserv 14:459-465. https://doi.org/10.1007/ s10841-010-9274-6

Plentovich S, Russell T, Fejeran CC (2018) Yellow crazy ants (Anoplolepis gracilipes) reduce numbers and impede development of a burrow-nesting seabird. Biol Invasions 20:77-86. https://doi.org/10. 1007/s10530-017-1516-Z

R Core Team (2019) R: a language and environment for statistical computing. R Foundation for Statistical Computing, Vienna, Austria. https://www.R-project.org/

Rexrode M, Abdel-Saheb I, Andersen JL (2008) Potential risks of labeled S-methoprene uses to the federally listed California red legged frog. Office of Pesticide Programs, US Environmental Protection Agency, Washington, DC

Sakamoto Y, Hayashi TI, Inoue MN, Ohnishi H, Kishimoto T, Goka K (2019) Effects of fipronil on nontarget ants and other invertebrates in a program for eradication of the Argentine ant, Linepithema humile. Sociobiology 66:227-238. https://doi.org/10.13102/sociobiology.v66i2.3772 
Schlappi D, Stroeymeyt N, Neumann P (2021) Unintentional effects of neonicotinoids in ants (Hymenoptera: Formicidae). Myrmecol News 31:181-184. https://doi.org/10.25849/myrmecol.news_031: 181

Simberloff D (1995) Why do introduced species appear to devastate islands more than mainland areas? Pac Sci 49:87-97

Singhal S, Hoskin CJ, Couper P, Potter S, Moritz C (2018) A framework for resolving cryptic species: a case study from the lizards of the Australian Wet Tropics. Syst Biol 67:1061-1075. https://doi.org/ 10.1093/sysbio/syy026

Smith MJ, Cogger H, Tiernan B, Maple D, Boland C, Napier F, Detto T, Smith P (2012) An oceanic island reptile community under threat: the decline of reptiles on Christmas Island, Indian Ocean. Herpetol Conserv Biol 7:206-218

Stork NE, Kitching RL, Davis NE, Abbott KL (2014) The impact of aerial baiting for control of the yellow crazy ant, Anoplolepis gracilipes, on canopy-dwelling arthropods and selected vertebrates on Christmas Island (Indian Ocean). Raffles Bull Zool 81-92

Suarez AV, Richmond JQ, Case TJ (2000) Prey selection in horned lizards following the invasion of Argentine ants in southern California. Ecol Appl 10:711-725

Tingle CC, Rother JA, Dewhurst CF, Lauer S, King WJ (2003) Fipronil: environmental fate, ecotoxicology, and human health concerns. Rev Environ Contam Toxicol 176:1-66. https://doi.org/10.1007/ 978-1-4899-7283-5_1

Turner G (2006) Communal egg-laying in Lampropholis coggeri and Saproscincus tetradactyla (Scincidae). Herpetofauna 36:88-92

Wetterer JK (2005) Worldwide distribution and potential spread of the long-legged ant, Anoplolepis gracilipes (Hymenoptera : Formicidae). Sociobiology 45:77-97

White EM, Wilson JC, Clarke AR (2006) Biotic indirect effects: a neglected concept in invasion biology. Divers Distrib 12:443-455. https://doi.org/10.1111/j.1366-9516.2006.00265.x

Wilhoft DC (1963) Reproduction in the tropical Australian skink, Leiolopisma rhomboidalis. Am Midl Nat 70:442-461. https://doi.org/10.2307/2423068

Wilson SK (2015) A field guide to reptiles of Queensland. Reed New Holland, Sydney

Yeeles P, Strain A, Lenancker P, Lach L (2021) Low reduction of invasive ant colony productivity with an insect growth regulator. Pest Manag Sci 77:1626-1632. https://doi.org/10.1002/ps.6181

Zuur AF, Ieno EN, Elphick CS (2010) A protocol for data exploration to avoid common statistical problems. Methods Ecol Evol 1(1):3-14. https://doi.org/10.1111/j.2041-210X.2009.00001.x

Publisher's Note Springer Nature remains neutral with regard to jurisdictional claims in published maps and institutional affiliations. 